\title{
SEAMEN, SCIENTISTS, HISTORIANS, AND STRATEGY PRESIDENTIAL ADDRESS, 1978
}

\author{
D. W. WATERS*
}

Wisdom, $n$. Being wise, (possession of) experience and knowledge together with the power of applying them critically or practically, sagacity...

Sagacity, $n$. The wisdom of experience.

Sage, $a$. \& $n .1$. . . having the wisdom of experience.

Scientific knowledge is predictive and practical. ${ }^{1}$ Historical knowledge is interpretive, but also practical. History is communication from the past with the present for the future. ${ }^{2}$ Historians are its agents; they accumulate, preserve, sift, and make available for transmission from one generation to another the knowledge of past experience that is necessary for rational action in the present and in the future. Science is the method of using history rationally. Historians of science may be forgiven if they assume that our professional strategists have made their preparations for war in the light of scientific predictions based upon quantitative knowledge of comparable operations in the past. The quantitative history of maritime and airborne operations of the last two world wars shows this assumption to be false. This address isolates a basic cause of, but does not attempt to explain, the social reasons for our strategists' ignorance of their professions' operational history; it does attempt to explain the irrationality and superficiality of their operational thinking, and it questions whether, in these fields of thought, history is repeating itself.

Despite the long history of navigation it has been unusual up to very recent times to associate seamen with science and scientists with seamen and the problems which they encounter at sea. There are, however, some notable precedents in history illustrating the practical value of employing civilian scientists to solve problems seamen-and, latterly, airmen-have found insoluble.

Seamanship is an art but its grounds are scientific. Pilotage, the art of conducting a ship in coastal waters and over short sea passages in a safe and timely manner, uses organized, positive knowledge of coasts, seabeds, sea states, and weather. Up to the latter half of the twelfth century AD European seamen practised pilotage only. Then, around 1200 , under the economic stimulus of a fast growing population, and of the Crusades in Iberia and the Levant, the manner in which ships in the

\footnotetext{
-National Maritime Museum, Greenwich, London SE10 9NF.

I wish to thank the editor, Dr Nicholas Fisher, for invaluable assistance in the presentation of this paper.
} 
Mediterranean made their way from port to port, and the time when they made it, were revolutionized.

The problem was how a ship could find her way from one port to another under the overcast skies prevalent in the Mediterranean between November and April. Since man first put to sea on long voyages (about $6000 \mathrm{BC}$ ) no one had put to sea during those six winter months. The fundamental invention - the technological breakthrough - which changed this was the magnetic compass. ${ }^{3}$ It did so because, irrespective of the visibility and the weather, it enabled the pilot to determine continuously the direction in which he was sailing. Whilst the inventor of the compass may have been a seaman, it is certain that exploitation of its full economic and military potential was referred to one or more mathematicians and geometers - scientists - for it could be achieved only through mathematics. ${ }^{4}$ Only a mathematician could solve the problems of a pilot's knowing not merely where he was going, but also where he was under overcast skies, how far he had to sail to reach his intended landfall and, when winds were adverse, on which courses he had to sail and for how long. By the mid-thirteenth century at the latest the pilot had been taught addition, subtraction, multiplication, and division in Arabic numerals; how to use a trigonometric table to calculate courses and distances to sail; the use of systematically written sailing directions; and how to plot his ship's progress regularly on a geometrically-constructed chart drawn to a scale of miles to check whether he was following his sailing directions; $;^{5}$ and how to predict rationally his expected time of arrival. We do not know by whom the various inventions were made, nor where, nor precisely when - here are problems crying out for some medievalist scholar with the instincts of Sherlock Holmes - but we do know why they were made: to improve the economic efficiency of ships.

The consequences were spectacular-a progressive lengthening of the sailing season until, before the end of the century, ships were sailing all the year round so that their delivery rate was roughly doubled, and there was a progressive extension of the geographical limits of their trade until, again before the end of the thirteenth century, Italian and Catalan ships were for the first time trading direct to the ports of the Narrow Seas-of the Low Countries and southern England. ${ }^{6}$

The story of scientists introducing revolutionary innovations at sea was repeated in the fifteenth century, when Prince Henry of Portugal, the so-called Navigator, called upon scientists to solve the problem of navigating in the Atlantic Ocean. The science of nautical astronomy resulted. ${ }^{7}$ The era of the great geographical discoveries of the world ensued.

Science advances by refinement of measurement and mathematical reasoning. From the time of the great discoveries, the outstanding problem preventing the efficient exploitation of the world's riches was the 
means of measuring scientifically a ship's longitude, her position eastwest on the globe. As late as the $1760 \mathrm{~s}$ it could be stated by the Astronomer Royal, Nevil Maskelyne, himself an experienced navigator, that no matter how prudent, how skilled a navigator might be, he might in the course of a long voyage be five, ten, or even fifteen degrees of longitude in error $;{ }^{8}$ or, to put this another way, he might be 300 miles in error after as little as fifteen days at sea. That the problem of longitude was ultimately solved was directly the result of improvements in the means of measuring time-and more particularly the difference of time between places. The basis of the solutions-for there were two methods, the lunar distance and the chronometer-were measurement and calculation, and rational prediction based upon the laws of physics, using the mathematical skills and physical knowledge slowly accumulated in the two centuries from Regiomontanus and Copernicus to Newton and Flamsteed and Mayer. Maskelyne's Nautical almanac, like Harrison's longitude machine, was the fruit of the accumulation and ingenious application of scientific speculation and invention, and in the 1760 s the two methods of measuring the 'so long desired' longitude of a ship at sea became practicable at last, with lunar distances giving an accuracy of within 30 to 60 miles, and the use of the chronometer giving longitude to within 3 to 6 miles, and ultimately to within 1 mile.

The solution to the longitude problem, while of immense commercial and stategic importance, was to give rise in the nineteenth century to a fundamental problem of naval warfare-how to find an enemy at sea. Not until the middle of the twentieth century (and during the second world war of that century) did still-perplexed British sea officers call belatedly upon civilian scientists to help them solve the problem. This was analogous to the navigational ones of the thirteenth, fifteenth, and eighteenth centuries so successfully solved by civilian scientists when called upon, for it was in principle a problem of position-finding-of finding where and when merchant ships were liable to be, and where and when an enemy ship (surface, submarine, or airborne) was likely to attack a merchant ship. Of course, the problem was not new. It has always been the main problem of war at sea-how to defeat attacks by small, highly mobile, virtually invisible warcraft upon almost defenceless, much less mobile, but far more numerous merchant and supply ships. These have continually to carry vital cargoes of food, fuel, raw materials, munitions, and men in diverse directions between Britain and (since the seventeenth century) the Americas, Africa, and Asia and, (since the eighteenth century) Australia.9 But since the early nineteenth century merchant ships had been in increasing numbers propelled mechnically instead of by sails, so they were unprecedentedly independent of the elements, and unpredictable in their movements. And by 1914 warcraft included submarines and aircraft, though it is doubtful whether they were any more difficult to 
detect or more elusive than the privateers and small swift craft that had wrought such havoc in the days of sail upon merchant ships sailing out of convoy of a warship ${ }^{10}$

You may well wonder why it was not until very recently that this problem of warfare at sea was seen by British seamen to be the critical one. After all, the British have a remarkable history of having been frequently at war, and almost always, since 1066, overseas. As the explanation involves historical research, or what might be called less grandiosely but more intriguingly, historical detective work, let me attempt to encapsulate the long and involved tale, for it is rich and tragic with the consequences of historical ignorance and of emotional, irrational thought, and non-mathematical reasoning. It is, therefore, a tale peculiarly appropriate for historians of science, as it illustrates the devastating consequences of the exercise of power by those placed in authority to wield it on the assumption that they have the knowledge, skill, and judgement necessary to enable them to do so with wisdom, when they have not.

From Renaissance times until the general propagation in the early nineteenth century of a reliable means to measure longitude at sea, the proven way-the only safe way-in which to make a landfall was for the navigator to observe his latitude, daily if possible, until he could position his ship on the latitude of, but two to three hundred miles to the east or to the west of, some conspicuous cape or island near his destination known as his 'landfall', and then sail west (or east), sounding the depth of the water frequently so as to gain timely forewarning that he was approaching land, until he sighted it. This was called 'running down the latitude' of a landfall. Having made his landfall, the navigator then proceeded to his destination by pilotage. Such landfalls were few and far between-on the west coast of Europe, Cape Clear, the Lizard, L'Oesant, Finsiterre, and Cape St. Vincent.

Very early in my naval career, when I was a midshipman, I began agonizing over how an admiral-after all, I aspired to be one one dayknew where to find an enemy. Had he, I asked myself often, a special ability, a sort of second sight which, clearly, he must develop over the years as a junior officer before he became an admiral, unless (unlike myself) he was, by some form of pre-destination, born with this ability? If I was right, some special faculty enabled him to find the enemy.

Nor was I alone in this belief, for certain thoughtful commanders and captains in the Royal Navy had started a journal, The naval review, at the very time that I was born; in this they discussed problems of strategy and tactics. As a consequence, I was informed by one of them, later ViceAdmiral K. G. B. Dewar, they were blacklisted in the Admiralty for presuming to discuss problems beyond their rank. Clearly, as there was then no Naval Staff, no Naval Staff College and (as now, disturbingly) no 
Senior Naval Officers' War College, the admirals and senior civil servants who administered the Royal Navy at that time must have believed, like me, that tactical sense, and strategic knowledge and insight, were the natural prerogative of all admirals on achieving that rank. As Admiral Dewar pungently if irreverently put it when I questioned him, 'From knowing nothing about strategy and tactics as captains, on the night that they hoisted their admiral's flag the Holy Ghost descended on them and they knew all the answers'.

It was not until some years after the end of the second world war that I discovered what 1 have dared to term elsewhere (in The naval review) 'the science of admiralty', the sure-fire, the only system of finding, fighting, and defeating an enemy at sea. ${ }^{11}$ This discovery was a result of seeking for mathematical patterns in naval operations. (I am not a mathematician, I hasten to add, and knew nothing of the science of naval operational research which was then still top secret.) I was a historian on the Naval Staff and as such I searched long for operational patterns because I had a sort of mystical belief in what Toulmin and Goodfield have since termed 'the powers of mathematical reasoning allied with honest observation', ${ }^{12}$ and because I had already perceived the phenomenon of recurrence in maritime operations, and I needed a rational explanation. ${ }^{13}$

First, with the help of the late Commander Freddy Barley, RNVR, I plotted on a navigational chart where all the major sea battles had been fought between the mid-seventeenth and early nineteenth centuries; then what had been the function of the opposing forces, asking what had they been doing and why had they been doing it when they met? For instance, had they been cruising around hunting, or had they been on a specific mission such as escorting a military or trade convoy to a strategic or commercial destination? The result, to the seeing eye, was a pictorial answer to the how, why, what, when, and where questions that, over the years, I had been asking myself in my search to acquire the ability of an admiral to bring an enemy to battle. For, as the plotting proceeded, an unambiguous pattern emerged. It revealed that these sea battles had been fought in the approaches to headlands and islands; in other words, on their latitudes. To anyone knowing the history of navigation over the period the navigational reaon for this battle pattern was obvious-each opponent had been 'running down the latitude' of a conspicuous landfall.

Next, I asked myself 'Why?'-'What was the operational reason? Why was one or other of the contending forces running down that latitude whilst the other was cruising on it?' The plot showed that every battle had been a convoy battle, that is, a battle between a force escorting merchant ships or supply ships and a force seeking to find and destroy ships. Clearly, in those pre-radar days, it was not second sight, but the exigencies of navigational limitations and of economy of force that had 
obliged successive generations of admirals to operate their forces where lay the highest practical probability of encountering and opposing an enemy on the most favourable terms. This was in the latitudes of conspicuous landfalls. The enemy would await the inevitable arrival of merchant ships running down the latitude but if these merchant ships were in convoy the enemy would be foiled, or be forced to fight to capture or sink ships. If ships approached their landfall independently, enemy raiders lying in wait had a field day. The only practicable way of protecting the hundreds of merchant ships and transports at sea at any time had been to concentrate them into convoys, often of hundreds of ships, and to concentrate the relatively few warships as escort and support forces to them, since navigationally the only way to make the land safely had been to run down the latitude of one of the very few safe landfalls on a coast. Admirals, I concluded, had listened to the Oracle, the wisdom of the wise woman: 'teach thyself to reason thus, there is no virtue like necessity' and acted accordingly. ${ }^{14}$

I also asked myself whether any other compulsion besides navigational necessity and paucity of warships had influenced the conduct of the operations, and discovered that the relative mercantile success of the convoy system as it operated had been continually monitored statistically on the insistence of the marine insurance market in London, and the results fed back to the Admiralty. The Admiralty rendered regular returns to Lloyds of convoyed and unconvoyed overseas sailings and losses. On the basis of these actuarial figures Lloyds underwriters charged differential marine insurance premiums, and these were significantly lower for ships which were sailed in and remained in convoy than those for ships which were sailed out of convoy, or which broke from convoy in the course of the voyage. The conclusion was clear. There had been further compulsion determining the pattern of operations; economics in the form of statistics. Throughout these wars, Lloyds' marine insurance market had provided the Admiralty with a reliable, realistic and continuous numerical measurement of the economic success or failure of its naval operations designed to ensure the safe and timely passage of ships. Furthermore, the records demonstrated consistently that convoy warfare was not only the most efficient method of protecting ships from attack and using them in the face of an enemy, but also the most efficient method of intercepting (of finding) an enemy and of forcing him to decisive action-to fight. ${ }^{15}$

When I was a naval aviator, we had a phrase to describe a landing on the heaving deck of an aircraft carrier in bad weather. With the mock bravado of youth, we called it 'Dicing with death'. 'Dicing' and 'death' were first studied mathematically in the mid-seventeenth century, in France and in England. 'Dicing' and life insurance, like marine underwriting, are forms of gambling. Dicing concerns the probability of a com- 
bination of dice occurring; life insurance, the probability of death occurring at a given age. As a former naval officer, I find it remarkable that the first scientific study in England of the probability of an event occurring should have coincided with the Navy's grappling with the problem of protecting as economically as practicable the merchants' ships against the probability of attack and loss in war, and introducing the convoy system as both the most economical commercially and the most efficient militarily. It was also coincidental with the growth of marine insurance in London, with the inception of Lloyds.

The convoy system so developed lasted just over 200 years but in the nineteenth century the ability of navigators to find longitude reliably, and the all-round mobility conferred on ships by steam propulsion, made 'latitude sailing' unnecessary. ${ }^{16}$ These technological factors, combined with an economic policy of laissez-faire, led in the 1870 s to the formal abolition by the British Parliament of the convoy system, hitherto operated so successfully in time of war, and to the formulation by strategists of a substitute philosophy of war. This was that merchant ships should be left to look after themselves in wartime so that, free of governmental control, they could operate commercially wherever they wished. Instead of being collected together at convoy assembly anchorages, such as Spithead and the Downs, effectively under the naval control of Customs and Excise officers until a naval escort force (up to a fleet of battleships) arrived to accompany them overseas till they arrived safely at their various convoy dispersal points, they were now to be free in war to clear from and enter any port at any time they wished. They could thus trade when, where, and how they wished, commercially as efficiently in wartime as in peace time. It would be safe for them to do so, the argument also ran, because the fleet would blockade the enemy forces within their bases whilst cruisers patrolled the so-called 'sea routes' and 'focal areas' (where the routes crossed or converged) to render them safe against enemy raiders. ${ }^{17}$

On a small-scale chart, and in the comfort of a shore-side closet, this philosophy of war may seem practicable, but the eyeball Mark I on board a ship was still the only way of detecting another ship at sea, both by day and by night, in fair weather and foul, and the means of signalling were similarly confined. Nevertheless, the theory ran, enemy forces which attacked merchant ships on the routes would be hunted by patrols-who would not, however, know where they were along the thousands of miles of innumerable routes. Curiously, such necessarily random searching (called 'hunting') operations were not ronsidered to be in defence of merchant ships but to be 'offensive'; on the other hand, operations including finding and fighting enemy forces in positions where they would have to be in order to sink ships, such as a convoy, were defined as 'purely defensive'. I mention this because professional dogma decreed 


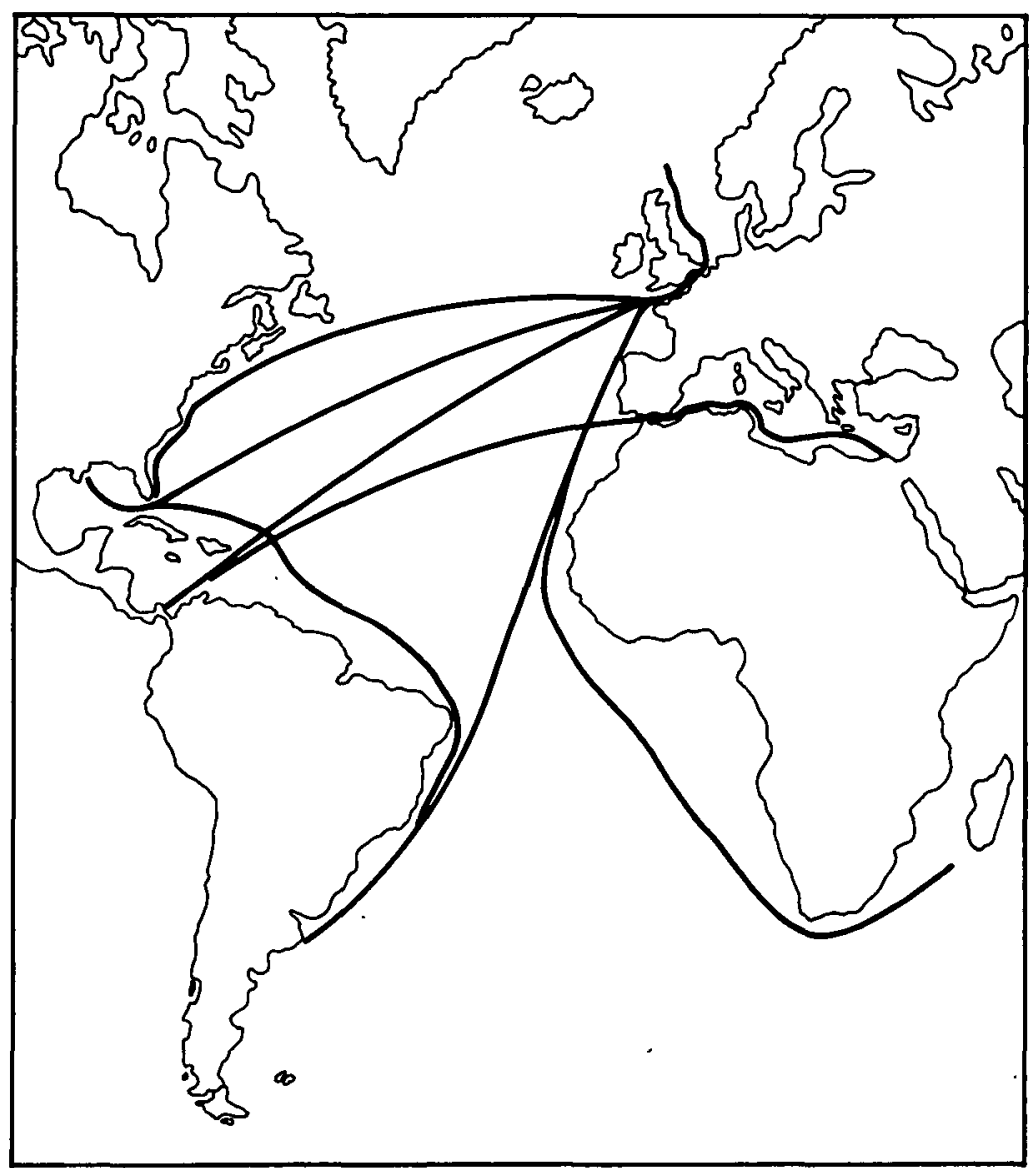

FIGi'RF 1. 'Sea lines of communication' or 'sea routes' in the Atlantic. For the past 100 years, strategists have thought, spoken, and planned in abstract terms of 'defending' our imaginary 'sea lines of communication', and have attempted to blockade enemy forces in their bases and to patrol these 'lines', leaving the ships to look after themselves. Results : catastrophic.

that a war could be won by 'offensive action' only. It followed logically from these definitions, that convoy operations although affording the highest probability of finding and fighting an enemy on favourable terms could only weaken the war-winning effort, and should therefore be eschewed.

Since the task of the Navy was no longer to ensure the safe and timely passage of individual merchant ships, this task came to be expressed as 'the protection of our sea lines of communication', the 'defence of our sea routes' by exercising our 'sea power' to 'gain command of the sea' by 'offensive action'. This, of course, contributed to the policy of hunting the enemy independently of the object of his attack and so, in practice, where he was least likely to be found. This abstract 
and unrealistic terminology obfuscated operational thought and strategic planning yet further. As the security of individual ships was no longer the Navy's concern there was no need for shipping statistics, and no need to communicate to the marine insurance market the circumstances of a ship's loss. In consequence, the statistical check previously operated by the marine insurance market on the efficiency-or inefficiency-of operations was inoperable and irrelevant. To confound matters further, with the mechanization of the Navy-its transformation from sail to steam-in the 1870s, all operational history was deemed obsolete, and its study for all practical purposes eliminated in favour of education in the new technology. Consequently, generation after generation of sea officers rose to the highest commands ignorant of the operational history of their profession, the only basis for the rational planning of war even in an age of new technology.

This late nineteenth-century philosophy of war with all its consequences was carried over into the twentieth century and, in the first half of it, remained dominant in two successive world wars, the first, of 1914-18, and the second, of 1939-45. As a consequence the Allies have twice in my lifetime been brought to within measurable distance of defeat. In the second world war this same philosophy applied by the Royal Air Force to the operation of fighting aircraft contributed massively to the Allied land, air, and sea disasters. ${ }^{18}$

At sea this form of warfare enabled enemy submarines in particular and, in the second world war, aircraft additionally, to inflict upon the Allies crippling losses of merchant ships at very small loss to themselves. In each war these disastrous consequences were eventually overcome and victory at sea over the enemy forces rapidly achieved by reverting belatedly to the convoy system of warfare operated with such success in earlier wars. Briefly, this system comprises Admiralty control over the movement of all ships, the regular sailing in groups of ships under threat of attack in company of warships and aircraft from convoy assembly to convoy dispersal ports or points, and reinforcing convoys with support forces when and where there is a high probability of attack (Fig. 3).

You may wonder why this convoy system of warfare was successful; why it wrested and kept the initiative from the enemy. It succeeds because first, it is systematic; secondly, because it is realistic, being based upon the movements of concrete entities-ships, warships, aircraft-of known operational parameters; thirdly, because operations can therefore be planned on the basis of mathematical calculation and rational prediction; fourthly, because the positions and movements of all convoys and their escort and support forces are at all times known to the authorities in operational control; and fifthly, because an enemy, if encountered, is confronted with a concentration of forces at the right time (and of course, at the right place) rationally calculated to defeat him-and if the enemy 


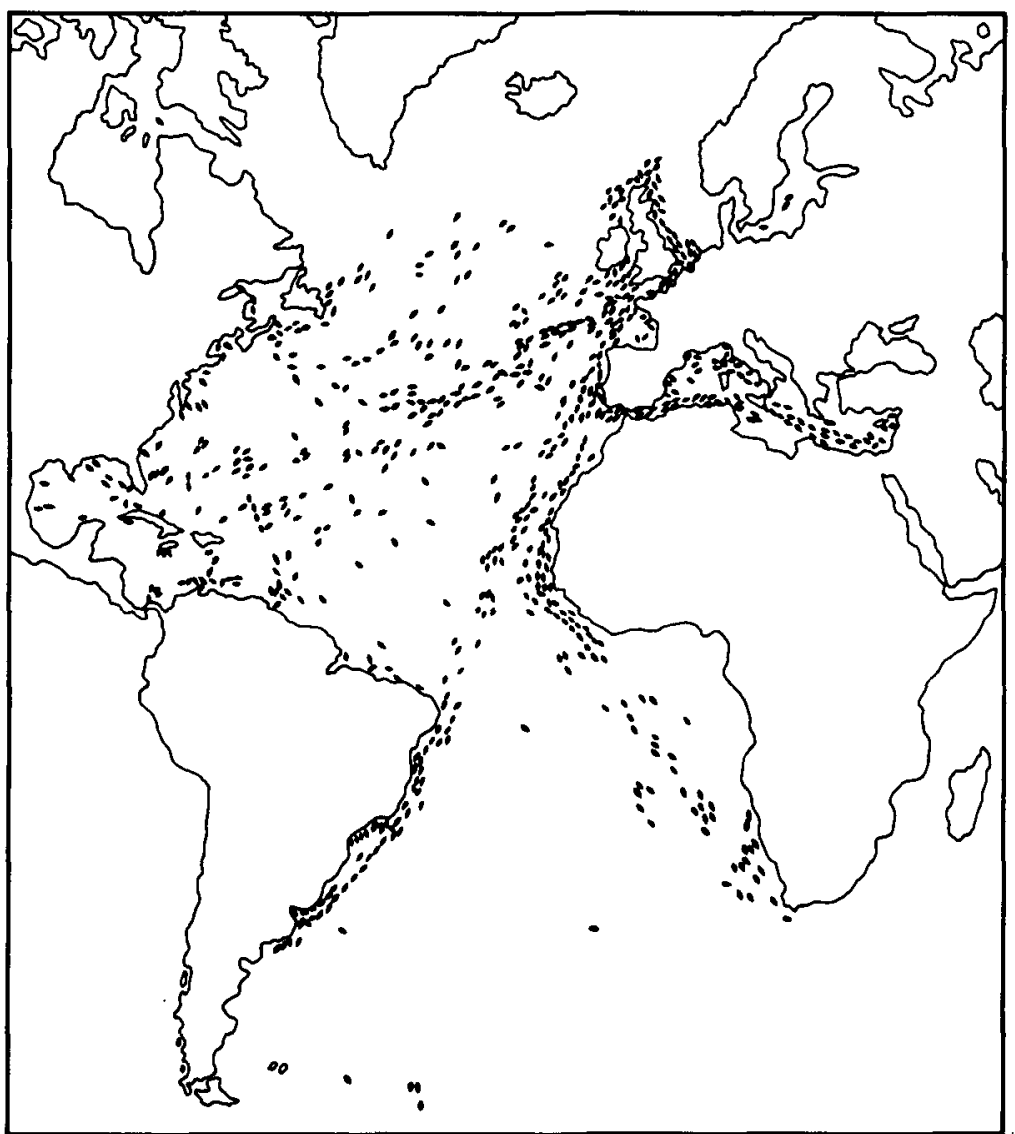

rigure 2. Typical distribution of independent ships in the Atlantic on any day (representational; actual numbers much greater).

dare not attack, he admits defeat. It is the most aggressive form of warfare practicable and, no less important, measurably the most efficient. Let these reasons suffice. There are others, but I leave them for your formulation. The convoy system with its few, constantly monitored, convoys at sea, optimized for our forces and ships all the operational advantages of intelligence, economy of effort, concentration of force, mobility, security, momentum, co-operation, surprise, and attack, whilst maintaining the object-the safe and timely arrival of the ships, where and when we wanted.

Because the Allies thought and termed convoy operation 'defensive', in each war they turned to convoy only as a desperate remedy forced on them by the enemy. They thought of it negatively, never as the warwinning operation which it could be, designed scientifically to achieve the highest probability of avoiding (if desired) or of encountering (if desired) 


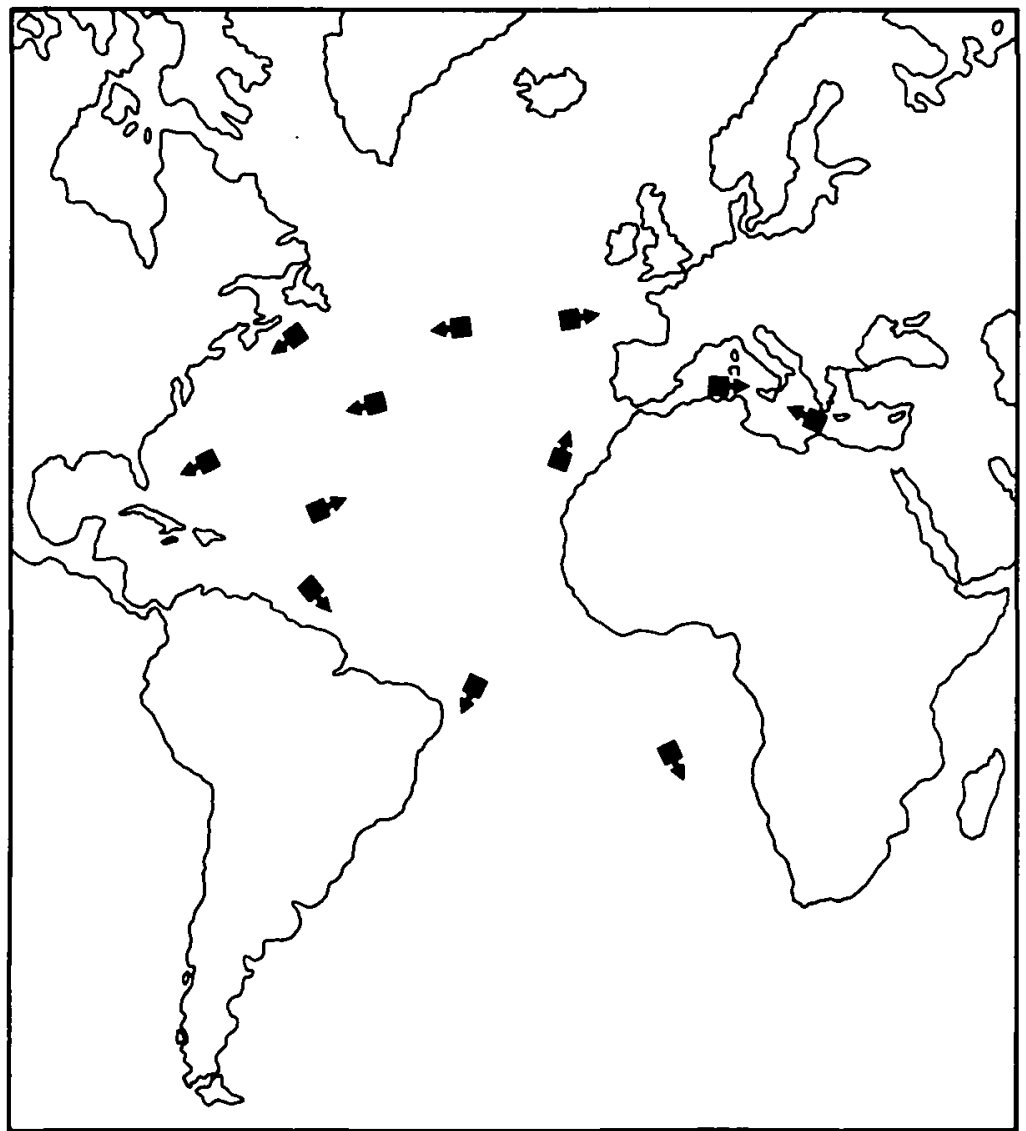

rIGURE 3. The equivalent ships in convoy in the Atlantic on any day (representational).

threatening enemy forces, and of doing so on terms most favourable to our co-ordinated merchant ships, warships, and aircraft, our locally overwhelming forces. In short, what I have termed elsewhere 'the mathematics of convoy', were not understood. ${ }^{19}$ Nor was it understood that convoy was the only systematic way of finding an enemy and forcing him to fight. It was a civilian, a lawyer by profession, Mr. Lloyd George (as he then was), the Prime Minister, who, in 1917, reintroduced the convoy system in the face of the entrenched opposition of the Admiralty. He questioned, listened surreptitiously to junior staff officers (amongst them the founders of The Naval review), and immediately grasped the principles of the system. Having had it introduced for cross-Channel shipping at the end of 1916 (at the insistence of the French), he at last got it adopted for ocean shipping in mid-1917, despite prolonged and continuing opposition. He also introduced a statistician-a Colonel Behrens, a railway statistician, into the Admiralty. The tide of war turned 


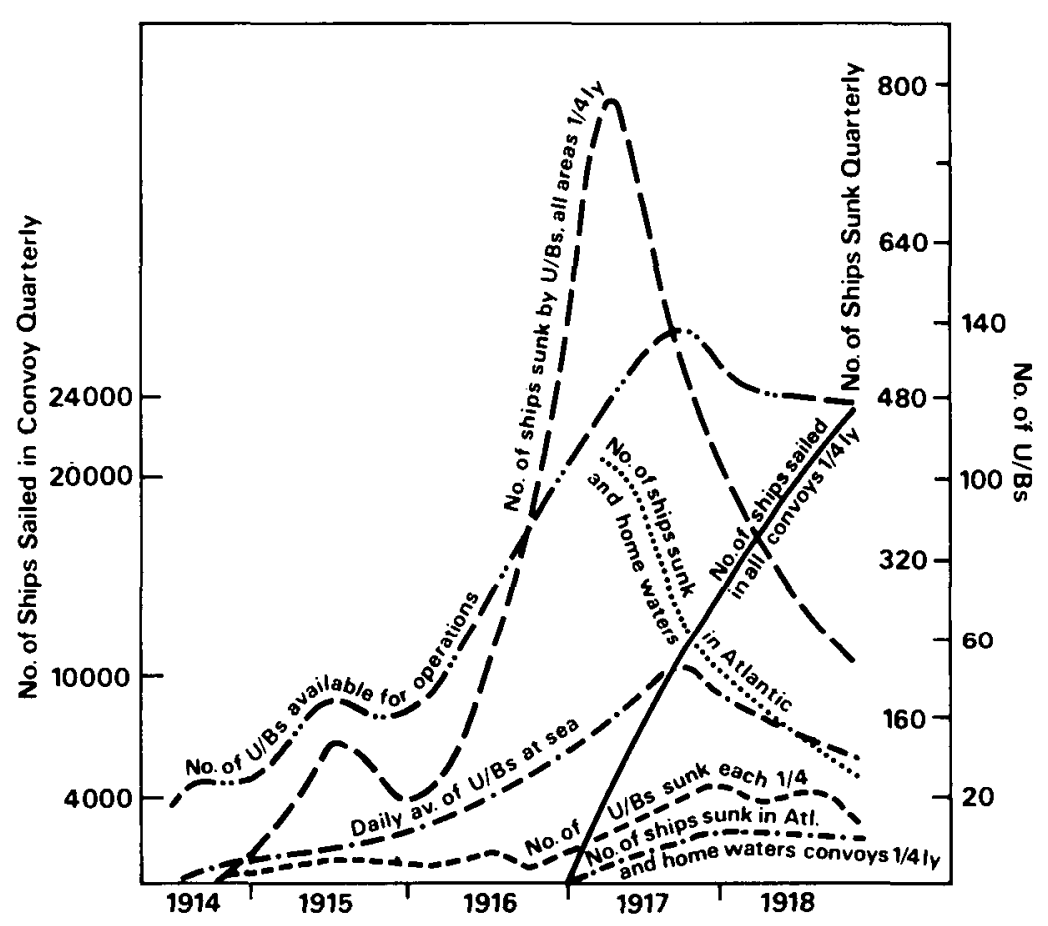

FIGURE 4. Effect of convoy system on the U-boat war, 1914-18.

Note 1. Five ships only sunk in convoy when air and surface anti-submarine escort present.

Note 2. Only a partial convoy system progressively operated.

dramatically (the statistics virtually speak for themselves). From imminent disaster the Allies quickly won victory (Fig. 4).

Civilian scientists were also called in during the First World War, but only to improve anti-submarine weapons and to advise on their tactical use once contact had been made with the elusive enemy. Finding the enemy-strategy-was, to the end of the war, left to the professional seamen and airmen.

The main anti-submarine effort was spent on 'offensive' hunting of U-boats. Of the 5,000 British warships in service in 1918 a mere $5 \%$ (250) were employed regularly as convoy escorts, and a further $10 \%(500)$ were used intermittently for support duties; thus at the most, 750 out of 5,000 warships were engaged on convoy operations. The use of aircraft was comparable. Yet wherever convoy was operated the shipping loss rate (the percentage of ships sunk of those sailed) was reduced tenfold, and in the Scandinavian trade 100-fold, from 25\% in the quarter ending April 1917 to $0.24 \%$ thereafter. Overall, the convoy loss rate was less than $0.5 \%$. In Home Waters and the Atlantic between February 1917 and October 1918, out of 84,000 ships sailed in convoy, U-boats sank 257 with torpedoes and 5 by mines; in the same period they sank by gunfire and torpedo 


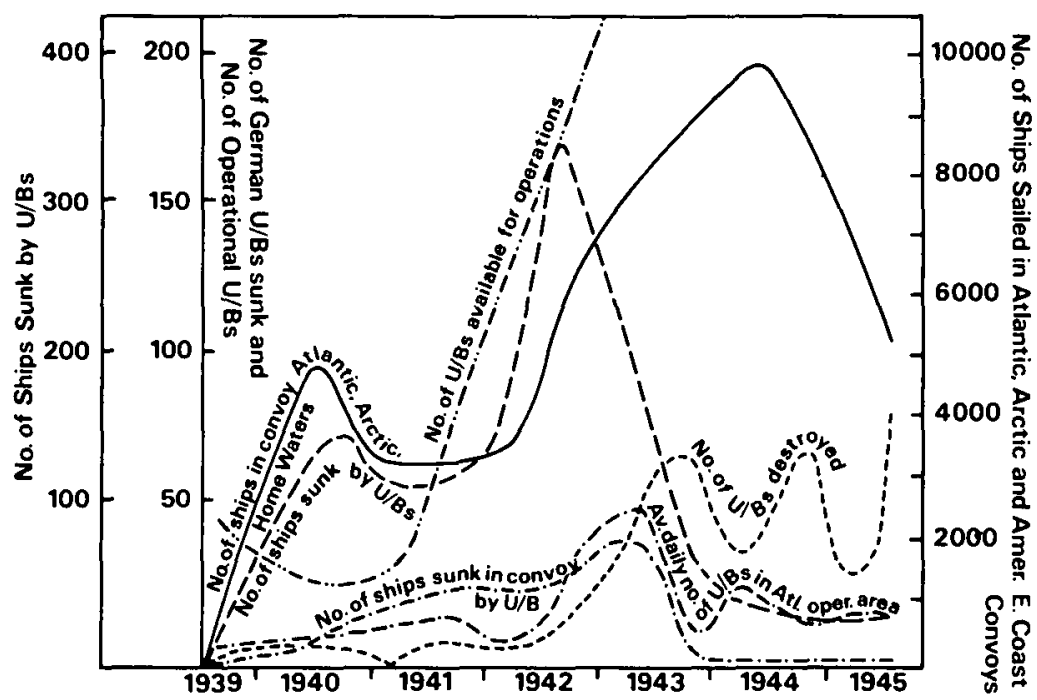

HIGI'RE 5. Effect of convoy system on the U-boat war, 1939-45.

Note 1 . Twenty-four ships only sunk in convoy when air and surface anti-submarine escort present. Note 2. Only a partial convoy system operated and progressively extended.

Note 3 . Figures represent quarterly movements and losses.

1,500 ships sailing independently, and 160 by mine. Only 5 of the convoyed ships were sunk when an air escort was present. As was later noted, one anti-submarine aircraft escort, whether armed or not, rendered a convoy with surface anti-submarine escort virtually immune from attack.

After the war, however, neither the Admiralty nor the Air Ministry studied how the U-boat attack on shipping had been defeated, and those involved left or were retired from their Services. No ships or aircraft were built or designed for anti-submarine convoy work.

On the outbreak of the Second World War in 1939 a partial convoy system was instituted, and imperfect and misleading statistics of sailings and losses were begun, and maintained throughout the war. As one consequence the value of convoy in terms of saving ships and of optimizing the delivery rate of ships (the amount of cargo delivered over a given period) was consistently underestimated, and so the mercantile value or efficiency seriously underrated. To cut a long, sad, story short, twothirds, about $67 \%$ of merchant ships sunk by U-boats in the second world war, were sailing independently or were deliberately excluded from convoy, and had loss rates always substantially higher than those of convoyed ships. I mean five times higher, and more; in some theatres, over some periods, 100 times higher (Figs. 5 and 6 ).

However, during the opening years of this second world war civilian scientists were called in first by the Air Ministry and then by the naval operational authorities to help with strategic problems; more specifically 


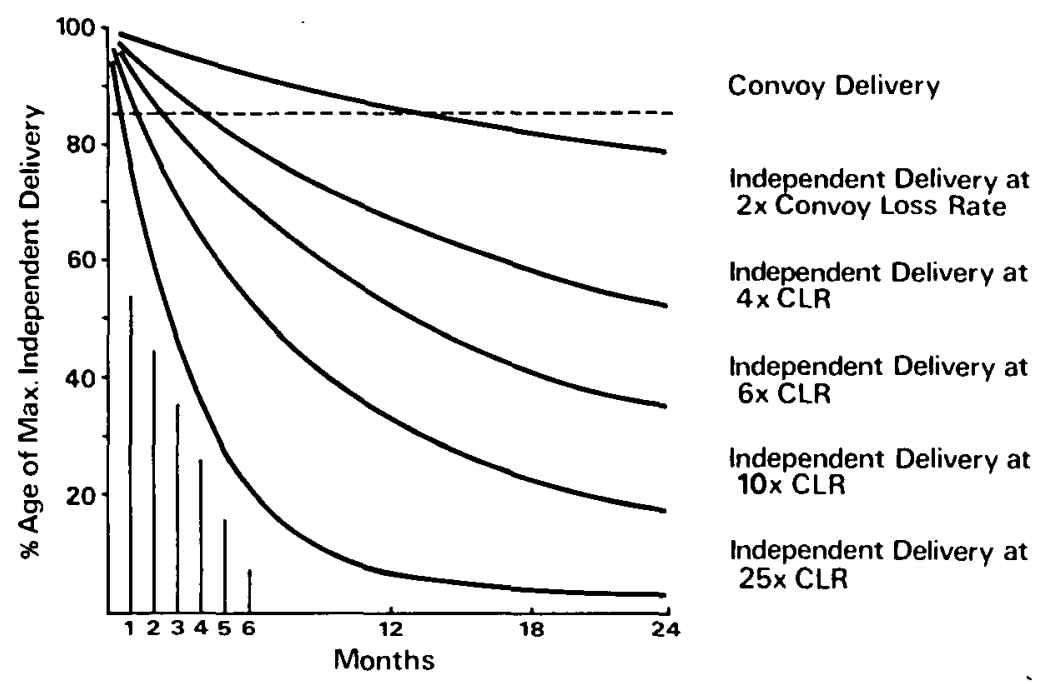

FIGURE 6. Delivery rates, convoy and independents.

to advise on how to improve the effectiveness of Allied forces hunting the enemy-chiefly U-boats-on so-called 'offensive patrols'. These were mostly carried out in sea areas where there were no Allied ships and which were therefore the operational areas, where, as the enemy's object was to sink ships, there was the least probability of finding an enemy. In 1942 convoy problems began to be considered-typically attention was focused on convoy last, but as ever this was logical, as convoys were (and are) still considered to be purely 'defensive' measures and so incapable of contributing to the defeat of the enemy.

Suffice it to say that by mathematical reasoning coupled with objective observation of numerical operational facts, the 'operational research scientists', often physicists and mathematicians, transformed a shipping situation in the Atlantic from one which, in the Spring of 1943, threatened imminent disaster to all Allied operations, into a clear-cut victory, between 23 May 1943 and the end of the war two years later. ${ }^{20}$

The key to Allied victory on all fronts lay in the relationship between the area of a circle (containing ships in convoy) and the defence perimeter (containing escorts) $\pi r^{2}$ and $2 \pi R$ (Figs. $8 \mathrm{a}, \mathrm{b}$ ), and upon the provision of one shore-based very-long-range aircraft with each threatened convoy in or near the mid-Atlantic-at most two at any one time. The operational research scientists showed first, that the larger a convoy was in number of ships, the safer were the ships in it. This was absolutely contrary to professional dogma, yet it had been recognized empirically and enforced by the Admiralty in the days of sail, and proved by the convoy records of the first world war, which at that time were still unstudied. ${ }^{21}$ Secondly, the scientists found that convoys with an anti- 

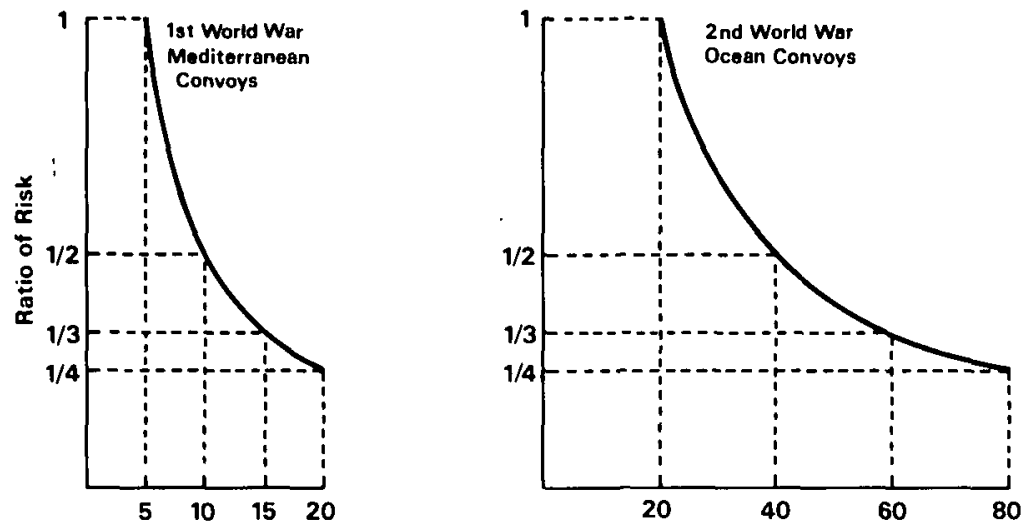

Average No. of Ships in Convoy

rIGURE 7. Casualties as a function of convoy size in two world wars.

submarine air escort were virtually immune from submarine attack. This operational fact of air warfare, of fundamental importance in war at sea, had been known operationally, you will recall, a mere twenty years before. It had since been ignored, at incalculable cost to this country and its Allies in numbers of ships sunk and cargoes lost, chiefly because the role of an aircraft with a convoy was defined as 'defensive'.

So deep-seated, so tenacious, was the dogmatic distinction between 'offensive' and 'defensive' action, that even the civilian scientists did not challenge it by assessing the relative efficiency of convoy operations and hunting operations in U-boat killing in realistic numerical terms of effort expended per U-boat sunk. Reliable statistics were available to do this and had it been done (for instance, had the number of hours flown and $\mathrm{U}$-boats sunk and aircraft lost on convoy escort been compared to the figures for 'offensive' hunting patrols), it would have been demonstrated conclusively that convoy escort was many times more efficient than 'offensive' hunting, in terms of U-boats sunk per hours flown and of aircrews and aircraft lost, to say nothing of ships saved. But nobody did. Nobody ever asked, 'What was the ship or the aircraft actually doing when it sank a U-boat? Escorting? Supporting a convoy? Or hunting?', in order to analyze the results to find out which was the most efficient way to sink U-boats and save ships in practice. As I discovered these and other operational facts after the war, facts far more precious than enemy intelligence because they were our own, easily accessible facts of direct and immediate operational value, I waxed indignanc. Yet, I reflected, who was I to be wiser than generations of admirals and air marshals, men of undoubted ability in leadership, organization, and administration and, some of them, in actual battle? Wondering this I then felt presumptuous. Yet I had knowledge which they should have had but had not had when 


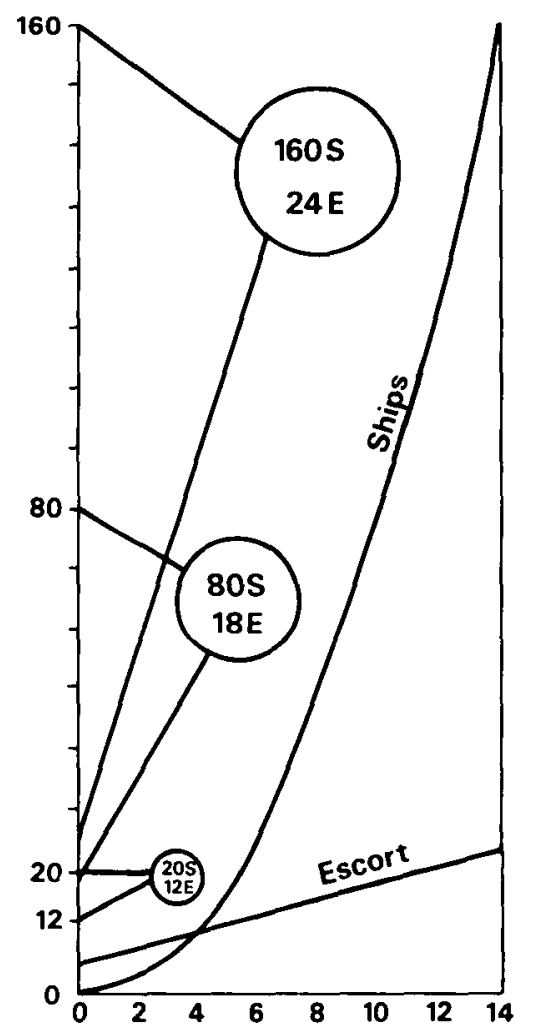

S - No. of Ships $\propto \pi r^{2} / S^{2}$

E - No. of Escorts $\approx 2 \pi(r+x) / y$

Sp - Ship Spacing

$r$ - Radius of Ships in Convoy

$R$ - Radius of Escorts $=r \cdot x$

$x$ - Distance of Screen from

Ship Perimeter

$y$ - Distance Apart of Escorts

Escorts 5 miles apart 5 miles outside perimeter of ships

spaced 2 miles apart

Radius in miles of ships in convoy at 2 mile spacing

FIGURE 8a. Exponential law of convoy escorts.

they needed it! Was this presumption? My indignation began to give way to contemplation. I was blessed with opportunity of leisure for I was being employed to think- a rare chance in a profession which prides itself on immediate action. I asked myself, 'Why? Why do clever men err? What is the originating cause?' I have asked myself these questions over the past thirty years, for though I may no longer be an active service sea officer, I once was, and one trained in the art of war at sea and in the air. And I am still an islander, ever conscious of the unseen ships upon whose safe passage in war as in peace my life, and all our lives, depend. And now at last I can answer those questions without self-doubt.

First, let me state unequivocally that, because the war at sea was the decisive conflict, the tragedy of the first world war was the Admiralty's, the Naval Staff's, ignorance of operational history. And because, again, the war at sea-the Battle of the Atlantic-was the decisive conflict, the tragedy of the second world war was the Air Ministry's, the Air Staff's, ignorance of operational history. ${ }^{22}$ 

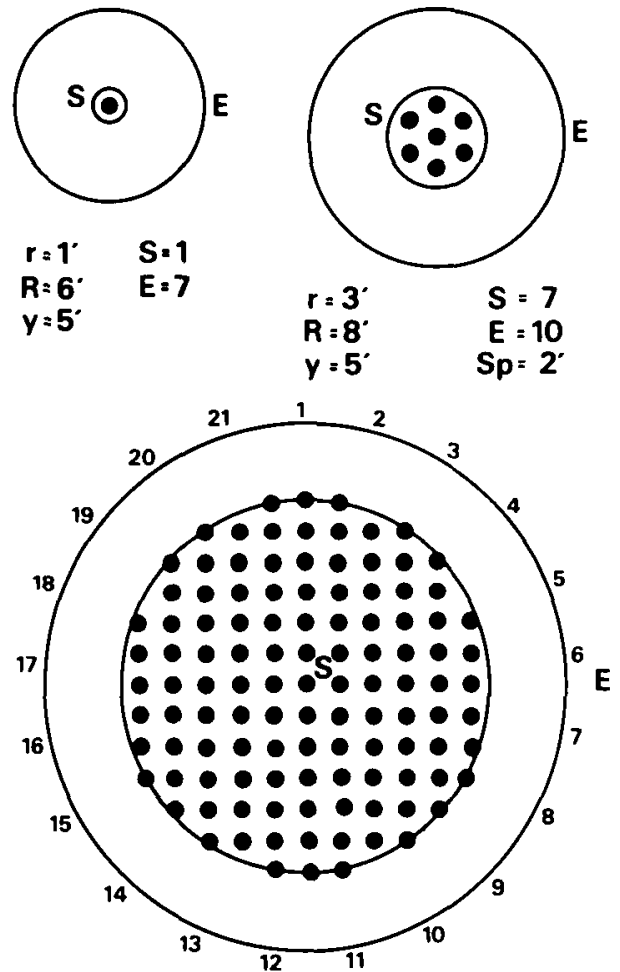

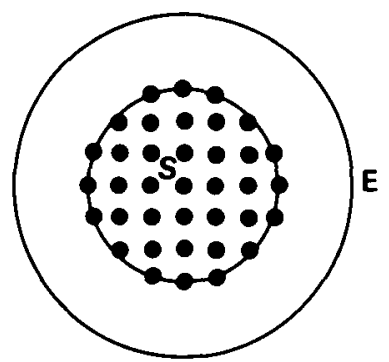

$$
\begin{array}{ll}
r=6^{\circ} & S=28 \\
R=11^{\circ} & E=14 \\
Y=5^{\circ} & S p=2
\end{array}
$$

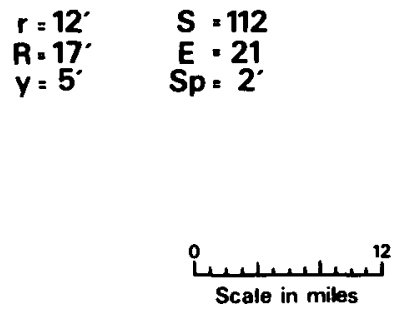

FIGURE 8b. Convoy: Ships (S) and escort (E).

Note. An air escort of one aircraft has in the past prevented virtually any attack. It is reasonable to predict that a nuclear submarine escort would have a comparable effect.

'Ignorance', the Oxford English dictionary defines as, 'Want of knowledge', adding '(of thing, or in general)'. What successive generations of fighting sea and air officers have had to a remarkable degree is 'want of knowledge' of operational history, of how and why war was waged at sea (and from the air) in the past, and currently. And they have also shown a singular want of knowledge of how to apply the discipline of their basically scientific and technological education to the formulation and solution of operational problems in the light of recent as well as more remote situations and events.

Why, if my postulate that they were clever and able men is correct, were they afflicted by this professional ignorance, as they demonstrably were? The answer lies in their education, what they were taught and what they were not taught; how they were taught to think and how they were not taught to think. They were (and, I'm afraid, still are) taught to think in abstract terms not susceptible of measurement-'sea power', 'air power', 'sea lines of communication'. 'Offensive' and 'defensive' action, are emotive terms, and so imprecise as to obscure reality. Would-be 
strategists were not taught to think in factual, concrete, realistic, calculable terms-'ships', 'aircraft', 'sink', 'save', 'efficiency'. They were taught literacy, but not the crucial importance of precision of operational thought and speech; they were taught numeracy, but not how to reason numerically operationally, so that in war they were operationally innumerate. This is why they did not understand the power of factual quantitative knowledge combined with numerical reasoning. ${ }^{23}$

During the second world war the need for this reason began to be understood, but 'through a glass, darkly', as St. Paul puts it. ${ }^{24}$ Numerical reasoning was introduced, most notably and successfully by Professor $P$. M. S. Blackett (as he then was, later Lord Blackett, PRS) as Director of Naval Operational Research from January 1942. But the most fundamental data, the accumulated, organized, quantitative facts of past war experience (other than of the immediate past) were ignored. I mean past operational history. Certainly operational research scientists did accumulate, and as they accumulated they studied operational casualty statistics and, finally, they produced by mathematical reasoning solutions to operational problems which had a rational probability of high efficiency. But all this, by its very nature, took time and cost casualties. It can be called the harvesting of the bitter fruits sown from past failures. And all the time, in the vaults of the Admiralty and of the Air Ministry, lay the organized comparable statistics of the first world war, available for immediate study and which, if studied, would have produced the same recommendations promptly, and at no cost. But no historian was consulted, nor employed to assist in the solution of current operational problems. I will not labour the point of what use could have been made of these statistics during the first world war, let alone during the inter-war period, by numerate historians of insight.

So, from demonstrating the need for naval and air officers to have a good education in the operational history of war at sea and in the air, I am now arguing that historians of the science (as distinct from the art) of war operations are no less important to a naval and air staff than operational research scientists, for "The thing that hath been is that which shall be; and that which is done is that which shall be done; and there is no new thing under the sun'. ${ }^{25}$ It takes a historian to find out and to communicate it.

To sum up, I believe in the power of thought. I believe forethought to be immeasurably superior in its results to mere muscle-power, or instinctive reaction. I believe also, from my study of history as from daily experience, that knowledge is power, that to have foreknowledge is to increase power; and I know that it is possible to derive from knowledge of past experience (history) foreknowledge of the probable course of future events-not in detail but in principle. This is a form of wisdom; it has given man dominion over the world. It depends upon the continuity 
of the availability of knowledge of past events, upon the acquisition, by study, of that knowledge and, if it is to be useful, upon the timely transmission of such knowledge by those who have it to those who will need it when right operational judgement is called for. But how and by whom this is to be organized is still, I fear, an unsolved - indeed, an unrecognized - problem.

In the seventeenth century there occurred a revolution in the way a relatively small number of influential men thought, the scientific revolution. From thinking qualitatively about natural phenomena these natural philosophers, as they called themselves, began to think quantitatively; instead of asking why something occurred and explaining it by qualitative reasoning as in the past, they began to ask first, what happened and how did it happen, and then they deduced, by quantitative, mathematical reasoning, universal laws which explained why. ${ }^{26}$

It appears to me that much operational thinking of the twentieth century is still in the sixteenth. It seeks to explain (and to train officers to think) qualitatively why operations should succeed, without first having found out quantitatively what such operations achieved in the past, at what relative efficiency, and whether universal operational laws can be deduced therefrom; laws which are deviated from only at crippling cost, but adhered to with the highest probability of operational efficiencysuccess. There are such operational laws (and some of them are appended below). They are the wisdom of war experience.

APPENDIX: OpERATIONAL LAWS

Risks to merchant ships and warships and attacking submarines

A. Ships sailed independently and submarines hunted independently ('offensively').

Risk to an independent ship of being detected and attacked varies directly as the number of ships $\left(N_{1}\right)$ at sea and directly as the number of submarines (U) at sea

Risk to submarine when attacking an independent ship of being sunk by an excort force $(E)$ is zero because $E=0$ and does not vary as the number of ships $\left(N_{1}\right)$ attacked because $\mathrm{E}=0$

$$
\begin{aligned}
& \left.R \propto N_{1}\right) \\
R & \propto U U \\
R & \propto N_{1} \cdot U \\
R & =0 \\
R & =N_{1} \cdot 0
\end{aligned}
$$

B. Ships sailed in convoy and submarines opposed by ('defensive') escorts of convoy.

Risk to a ship in convoy of being attacked varies inversely as the size ( $S$, number of ships) of the convoy

$$
\mathrm{R} \alpha \frac{1}{\mathrm{~S}}
$$

and directly as the number of convoys $\left(N_{c}\right)$ at 
and directly with the number of submarines $(U)$ at sea

$$
\begin{aligned}
& \mathrm{R} a \mathrm{U} \\
\therefore & \mathrm{R} \alpha \frac{\mathrm{N}_{\mathrm{r}} \mathrm{U}}{\mathrm{S}}
\end{aligned}
$$

It follows that the larger the convoy and the fewer the convoys, the smaller is the risk to a ship in convoy of being attacked

In the absence of air escort the loss (L) of ships in convoy varies directly as the number of submarines (U) attacking and inversely as the number of escorts (E) with the convoy

$$
\begin{array}{r}
\quad L \alpha U \\
\quad L \alpha \frac{1}{E} \\
\therefore \quad L \alpha \frac{U}{E}
\end{array}
$$

Risk of loss to submarines attacking ships in convoy

The number of submarines sunk $(K)$ by surface escorts when attacking a convoy varies directly as the number of attacking submarines (U) and directly as the number of escorts (E) with the convoy

The measure of success: exchange rate

For an enemy attacking shipping the yardstick measuring victory or defeat is

Submarines sunk while attacking convoys $(\mathrm{K})$ per ships sunk in convoy (L)

This was the German yardstick, 1939-45. It was not used by the Allies.

The $E^{2}$ law of convoy escorts

This yardstick also measures the value of escorts $(\mathrm{E})$ with a convoy. It was formulated by Blackett in 1943

From (13), (16), and (17)

$$
\begin{aligned}
& \frac{K}{L} \alpha \frac{U}{U}{ }^{\frac{U}{E}} \\
\therefore & \frac{K}{L} a E^{2}
\end{aligned}
$$

Thus the operational value of anti-submarine forces, measured in terms of the critical operational exchange rate 'submarines sunk per ship sunk' is proportional to the square of the number of escorts when they are used as convoy escorts, that is, when deployed tactically with convoys, but not when they are employed in any other way, for example on 'offensive' hunting patrol. This $E^{2}$ law applies, of course, to aircraft and to nuclear submarines when they are used as convoy escorts.

The value of hunting patrols is measured by the exchange rate 'independent ships sunk by submarines' per

'submarines sunk by hunting patrols'. 
The exponential law of escorts

The number of escorts (E) required to protect a convoy varies as rather less than the square root of the number of ships (S) in convoy

It follows that the larger the convoy, the fewer the escorts required.

\author{
Risk of loss and inter-ship spacing \\ Each doubling of inter-ship spacing in convoy \\ reduces the risk of loss by $75 \%$, but increases the \\ defence perimeter of the convoy by only about $50 \%$
}

Acknowledgement: The late Lord Blackett, PRS, did much fundamental work in the elucidation of these l.aws when Director of Naval Operational Research during the second world war. I was assisted in my researches by the late Commander F. Barley, RNVR, and in formulating and expressing Laws (1-9), (17) and (19), and in qualifying Laws (11-13) by Dr W. E. Dawson of the Operational Research Department in the course of discussions and research in the Admiralty in the $1950 \mathrm{~s}$.

\title{
NOTES
}

' J. Bronowski, The visionary eye, Cambridge, Mass. \& London, 1979, p. 59.

2 Personal communication from Dr A. R. Michaelis, editor of Interdisciplinary science review, c1978.

3 F.C. Lane, 'The ecomonic meaning of the invention of the compass', American historical review, $1963,68,605-17$.

4 E. G. R. Taylor, 'Mathematics and the navigator in the thirteenth century', Journal of the (Royal) Institute of Navigation, 1960, 13, 1-12.

- These were the first scale drawings constructed in Europe since classical times. Ptolemaic maps were of course the first scale drawings, but these were unknown in the west until the early fifteenth century. The first architectural drawings to scale were devised early in the fifteenth century, probably by Brunelleschi; see A. J. Pacey, The maze of ingenuity, London, 1974, p. 97.

- A. A. Ruddock, Italian merchants and shipping in Southampton, 1270-1600, Southampton, 1951, Pp. 19-21.

7 D. W. Waters, Science and the techniques of navigation in the renaissance, Greenwich, 1976, contains exhaustive references.

- N. Maskelyne, The British mariner's guide, London, 1763, 'Introduction'.

- D. W. Waters, 'The philosophy and conduct of maritime war, 1815-1945', Joumal of the Royal Naval Scientific Service, 1958, 13, 109-19, 183-92.

10 D. W. Waters, 'The science of Admiralty, iv: Convoy in the age of sail, 1204-1874', The naval review, $1964,52,179-94$.

"D. W. Waters, 'The science of Admiralty, vi', ibid., pp. 423-37 (423).

12 S. Toulmin and J. Goodfield, The fabric of the heavens, London, 1963, p. 201.

13 It was not until many years after I had left the Admiralty that I read A. N. Whitehead, Science in the modern world, London, 1925 (reprinted with a preface by J.Z. Young, London, 1975). His discussion of recurrence and periodicity (reprint, pp. 45-6) indirectly illuminates this aspect of operations.

14 William Shakespeare, Richard II, I, iii, 275.

is Waters, op. cit. (10), pp. 185-6.

16 Waters, op. cit. (9), pp. 109-13.

17 In Science and the modern world, Whitehead observed, 'There is an error . . of mistaking the abstract for the concrete. It is an example of ... the fallacy of misplaced concreteness. This fallacy is the occasion of great confusion in philosophy'. Whitehead was referring to cosmological philosophy. The use of the terms 'sea routes' or 'supply lines' in place of the word 'ships' in the philosophy of war is a classical example of 'the fallacy of misplaced concreteness'. Unlike ships which are concrete realities, 'sea routes' and 'supply lines' are figments of the imagination, they cannot be sunk nor can they deliver any supplies. The consequences of the great confusion that ensued illustrates precisely the truth that Professor Young states in his preface to Whitehead's study: 'Once we have given a name to some abstract entity or quality we tend to apply to it the same grammatical treatment as we should give an object that could be seen and touched'; Whitehead, op. cit. (18, reprint), pp. 7, 68. See Figs. 1 and 2 in the text above. 
18 'Misplacèd concreteness' in relation to aircraft, e.g., the use of 'air power' instead of 'aircraft', has confused strategic thought in Britain and America with grave consequences. In many influential strategists' imaginings 'air power' was to do (and still does) things which it was (and is) demonstrably impossible for aircraft and aircrews to do within the limitations imposed upon their activities in war by the parameters of their operational performance and training. A classic example of this is embodied in the expectations, miscalculations, and realities of the British 'strategic bombing' in the second world war; see P. M.S. Blackett, 'Operational research: recollections of problems studied, 1940-1945', in Brassey's annual: the armed forces year-book 1953, London, 1953, pp. 88-106; and the officially compiled quantitative Strategic bombing surveys of the European and Pacific theatres, printed in 1945 but still, I believe, unpublished in this country.

19 D. W. Waters, 'The mathematics of convoy', Navy international, May 1978, pp. $22 \mathrm{ff}$.

20 Blackett, op. cit. (18), especially pp. 102-6.

2 D. W. Waters, 'The science of Admiralty, i and ii', The naval review, 1963, 51, 395-402 (399-401).

22 Ibid.; and 'The science of Admiralty, iii', ibid., 1964, 52, 15-26; 'iv', 179-94; 'v', 291-309; 'vi', 423-37. For the responsibility of the Air Ministry for maritime aircraft, see Waters, op. cit. (9), p. 183.

${ }_{23}$ 'The really vital problems were found by the operational research groups themselves, rather than given them to solve by the Service operational staffs'; Blackett, op. cit. (18), p. 106.

24 I Corinthians, XIII, 12.

25 Ecclesiastes, I, 9. See Figs. 4 and 5.

26 As Whitehead so lucidly put it, "The originality of mathematics consists in the fact that in mathematical science connections between things are exhibited which, apart from the agency of the human reason, are extremely unobvious'; op. cit. (13), p. 32.

APPENDIX NOTES

27 If $N_{1}=100$ and $U=10$, then $R \propto 100 \times 10$ $\propto 1,000$.

28 If $S=100, N_{c}=1$, and $U=10$, then $R \propto \frac{160}{10}$ $\propto \frac{10}{10}$.

$R \propto c_{\frac{1}{b}}^{1}$ because in each war a U-boat sank on average only one ship in convoy per attack.

29 This age-old operational law was rediscovered and applied by Admiralty operational research scientists in early 1943. It was one of the keys to victory; the U-boats were defeated by 23 May 1943. In the next two years U-boats sank only 12 ships (all in the absence of air escort) from convoys in the Atlantic.

30 If $U=10$ and $E=10$, then $L=10=1$.

31 There are factors of proportionality applicable to these laws. Thus in 1941-42, the equations were approximately $5 \cdot \frac{U}{E}$ and $\frac{U . E}{100}$

32 In each war this exchange rate was ten times as costly to the Allies as the convoy exchange rate. However, it was never evaluated by the Allies in either war, and nor was the convoy exchange rate (Law 17). The only exchange rate the allies used, from time to time, was 'all ships sunk by submarines' per 'submarines sunk by all means', which was useless. It gave no measure of the relative efficiency of different anti-submarine and shipping defence operations. Thus it gave no measureas Law (17) did to the U-boat Command in world war I - of the cost of sinking a ship in convoy in terms of submarines sunk in the process.

The 'convoy' and 'independent hunting' exchange rates when compared give of course a measure of the efficiency of convoy as opposed to hunting as an operation of war. In each war it was about ten times as efficient as hunting.

33 This was another key to the victory in 1943. See also Law (10), and Figs. 8a and 8b. See also n.29, above.

${ }^{34}$ Inter-ship spacing was increased in the spring of 1943 as a result of the elucidation of this Law, and this was another factor contributing to the victory of May 1943. It was adopted because the relationship between the area of a circle and its perimeter being understood, it was apparent that with a reduction in the number of convoys there would be a sufficiency of escorts, although the fewer convoys sailed were larger. 